\title{
Accumulation and Retention of Tritium (Tritiated Water) in Larval Fish (Carassius gibelio) and Radio Toxicological Effect
}

\author{
Lydia Bondareva* \\ Federal Scientific Centre named after F.F. Erisman, Russia
}

Submission: July 17, 2017; Published: October 12, 2017

*Corresponding author: Lydia Bondareva, Federal Scientific Centre named after F.F. Erisman, Mytischi, Moscow region, Semashko street, Russia, Email: lydiabondareva@gmail.com

\begin{abstract}
Larvae Carassiusgibelio were developed artificially in the laboratory and exposed to 50, 500, 5000 and $50000 \mathrm{BqL}^{-1}$ tritium (biological grad) contaminated spring water. After 28 days exposure, selected lots larvae were removed to inactive free-flowing water to study retention and turnover components. Distinction between volatile or "body-water" tritium and non-volatile or "bound" tritium was emphasized. A rapid uptake of tritium during 1 to 2 days was indicated for all concentrations, followed during the ensuing 27 to 28 days of exposure by maintenance of equilibrium levels. The "bound" tritium fraction accounted for approximately $20 \%$ of the total label in each larva, a level not exceeded as measured over the duration of exposure. Both volatile and "bound" fractions, after transfer to free-flowing water, elute rapidly with estimated half-times of 1 and 2 hours, respectively.
\end{abstract}

The effects of each treatment on larvae was assessed in of the proportions the number abnormal size of the larvae. Selected behavioral and physiological test were applied to detect "sub-lethal" effect. Preliminary consideration of all data indicated that no significant degree of detriment resulted from exposure at these levels during development of larvae.

Keywords: Tritium; Larvae; Radiological effect; Radio toxicology

\section{Introduction}

Tritium $\left({ }^{3} \mathrm{H}\right)$ in the natural environment is derived from natural or anthropogenic sources and can be used to estimate human radiation exposure around nuclear fuel reprocessing facilities. Elevated concentrations of ${ }^{3} \mathrm{H}$ in the environment are generally associated with its production at nuclear facilities and exposure of local populations can be a public concern. The concentration of cosmogenic ${ }^{3} \mathrm{H}$ in natural waters is estimated to be $0.1 \mathrm{BqL}^{-1}[1,2]$. In continental environments, which are not directly adjacent to nuclear facilities, the radioactivity concentrations of ${ }^{3} \mathrm{H}$ ("background") currently range between 1 and $4 \mathrm{BqL}^{-1}$.

The difference between these and cosmogenic background levels ( 0.1 to $0.6 \mathrm{BqL}^{-1}$ ) can be accounted for by the decreasing influence of fallout from nuclear weapons testing in the atmosphere, which, in the case of ${ }^{3} \mathrm{H}$, resulted in maximum activity concentrations of nearly $470 \mathrm{BqL}^{-1}$ in rainwater in 1963. Because ${ }^{3} \mathrm{H}$ is an isotope of hydrogen, it enters the hydrological cycle primarily as tritiated water (HTO) and in the form of tritiated-organic carbon-based compounds [1,3]. Thus, its entrance into the biosphere, migration, bioaccumulation, and pharmacodynamics in higher organisms can be described generally by the behavior of water, as well as by the metabolism of tritiated-organic carbon based compounds. Through these pathways, ${ }^{3} \mathrm{H}$ can become bio available and bio accumulate in higher organisms through tropic levels and eventually, can be taken up by humans $[4,5]$. Thus, it is important to understand the potential source terms and levels of ${ }^{3} \mathrm{H}$ that contribute to ecosystems in which humans might be impacted.

Exerting a poly tropic effect on organs and tissues of a living body, tritium is a considerably more toxic radio nuclide than other $\gamma$-and $\beta$-emitters $\left({ }^{137} \mathrm{Cs},{ }^{106} \mathrm{Ru}\right)$ with similar distribution pattern, because it creates 10-30 times higher ionization density in unit volume of the tissue. In addition, tritium exhibits transmutagenic action and can cause genetic effects. According to the UN data (1988), tritium is one of the seven most hazardous radionuclides along with ${ }^{137} \mathrm{Cs},{ }^{14} \mathrm{C},{ }^{32} \mathrm{P},{ }^{226} \mathrm{Ra},{ }^{23} 9 \mathrm{Pu}$, and ${ }^{241} \mathrm{Am}$ $[1,6]$. Tritium is also characterized by high migration ability.

When getting into the environment, it becomes instantaneously involved in all the units of the ecological turnover, replacing protium and causing breaks in RNA and 
DNA chains in biological structures of all living bodies [5,711]. Specifically OBT passing along the entire food chain is the most biologically hazardous compared to tritium water (HTO), which is also a source and a factor of the living body irradiation, replacing protium water $\left(\mathrm{H}_{2} \mathrm{O}\right)[4,12]$. If the living organism was exposed to higher environmental ${ }^{3} \mathrm{H}$ concentration in the past than in the present, past contamination may remain in some of its tissue.

This is one of the reasons for the high OBT/HTO rations in nature. The biological consequences of low level irradiation have become an important consideration in all environments. Knowledge in the aquatic areas is, however extremely limited, and is mainly concerned 8 with somatic effects. Since tritium will be a major contributor to the radioactivity in the effluents from nuclear power plants and cannot be removed by conventional technology increasing concern has been expressed as to the ultimate, concentration in and the effect. Most available experimental data is concerned with the effects of acute exposures of radiation. While these data indicate that fish and other aquatic organisms are relatively radio resistant in comparison with terrestrial mammals, little pertinent data is available for an assessment of the effects of low-level arid chronic exposure regimens.

\section{Materials and Methods}

Larvae of the fish (Carassius gibelio) were developed artificially, in the laboratory, water hardened and at $6 \mathrm{hr}$ after fertilization were immersed in 50, 500, 5000and $50000 \mathrm{BqL}^{-1}$ tritium which were added in water (essentially pathogen free). The experimental conditions were: 28 days at $10.5 \pm 2.50 \mathrm{C}$, facilitated within are circulating drip incubation system. Water and embryos were sampled at intervals to ascertain the time necessary to reach equilibrium.

After experiment, larvae were rapidly frozen and stored at $40{ }^{\circ} \mathrm{C}$. Immediately before the measurements of the content of tritium the larvae was then placed within the oxidizer unit and subjected to an instrument heat of $200{ }^{\circ} \mathrm{C}$, and low flow of $\mathrm{N}_{2}$ gas was used to sweep the evolved volatile tritium fraction. After the samples were placed into a round-bottom flask, where the sample was mixed with toluene in readiness for azeotropic distillation. The mixture obtained was allowed to stand in the corked flask for $12 \mathrm{~h}$ and was then placed into a flask-heater. A special device was fitted onto mouth of the flask, which had been developed by the authors, for azeotropic distillation and separation of the aqueous and organic phase [13].

If required, further purification from organic impurities was accomplished by re-distillation with $\mathrm{KMnO}_{4}$ [14], until a transparent and colorless liquid was obtained. Following distillation, aliquots were mixed with the liquid scintillation cocktail and prepared for radioactivity measurements. The purified sample aliquots were mixed with Ultima Gold AB liquid scintillation cocktail in polyethylene vials at a ratio of $1: 1$; three background samples were simultaneously prepared. Standard tritiated water, with a certified value of $0.1 \mathrm{~Bq} \cdot \mathrm{L}^{-1}$, was used as a reference for each type of sample measured. The samples, backgrounds, and ${ }^{3} \mathrm{H}$ references were stored in the system for at least one day to sufficiently decrease chemilum in escence, which interferes with ${ }^{3} \mathrm{H}$ measurement. All vials were then counted using a Quantulus Model 1220 liquid scintillation counter (200 min/sample, cycle-7 times, total measuring time per sample $1400 \mathrm{~min}$, measuring region $-0.0-18.6 \mathrm{keV}$, corrected appropriately using a quench indicating parameter (i.e. transformed Spectral Index of External standard, TSIE) [15].

The measurement efficiency $\varepsilon$ was calculated using the standard method [16] by the formula $\varepsilon=\overline{\mathrm{I}} / \mathrm{A}$, where $\overline{\mathrm{I}}$ is the sample counting rate, and Ais the sample radioactivity in DPM (disintegration per minute) units, calculated from the data indicated for the reference sample [16]. For the conditions used for the tritium determination in the samples, the efficiency was $26-28 \%$. The absolute sample activity was found from its true counting rate, knowing the detection coefficient $\varphi$. The absolute activity was determined using the method of relative measurements. The method is based on comparison under strictly identical conditions of the counting rates from a test (or control) sample $\left(I_{x}\right)$ and from a reference (standard) sample $\left(I_{s t}\right)$ containing a known amount of the radionuclide [16].

Because the samples contained the same radionuclide, the detection coefficient $\varphi$ under identical measurement conditions will be the same. Then, the absolute activity $\left(A_{x}\right)$ determined by the method of relative measurements will be [16] $\mathrm{Ax}=(\mathrm{Ix} / \mathrm{Ist})$ Ast. The background determined for the $3 \mathrm{H}$-free water samples prepared ranged between 0.926 CPM and 1.002 CPM and the counting efficiency, using the internal standard method [17-19], was between $25.37 \%$ and $26.10 \%$ for the maximum figure of merit.

\section{Radiation Effects}

The effects of each treatment were assessed in terms of the proportions and the numbers of obviously abnormal larvae. Anomalies included major malformations of the eyes and of the body. The larvae were inspected each day and all dead larvae removed. Selected behavioral and physiological tests were applied to detect "sub-lethal" effect. The relative performance of tritium-treated $\left(5000 \mathrm{~Bq} \mathrm{~L} \mathrm{~L}^{-1}\right.$ exposures for 28 days) and untreated (control) juvenile fish was determined using the method which was described by Bams [20] and Bayley et al. [21]. For other groups of tritium-stressed fish $\left(500 \mathrm{~Bq} \mathrm{~L}^{-1}\right.$ exposures for 28 days), equilibrium loss and thermal death times were determined.

\section{Results and Discussion}

\section{Accumulation and Incorporation}

A rapid uptake of tritium during the first 1 to 2 days was demonstrated at all concentration levels; this was followed during the ensuing 23 to 28 days of exposure by maintenance of equilibrium levels. The uptake for both volatile and "bound" 
fractions at the $500 \mathrm{~Bq} \mathrm{~L}^{-1}$ levels illustrated in Figure 1. The part tritium fraction accounts for approximately $20 \%$ of the total label in each larva, a level not exceeded as determined over the duration of exposure.

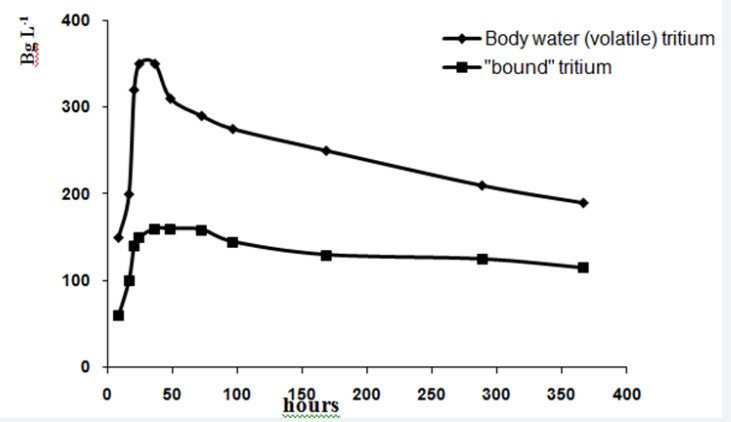

Figure 1: Accumulation of tritium in eggs of Carassiusgibelio

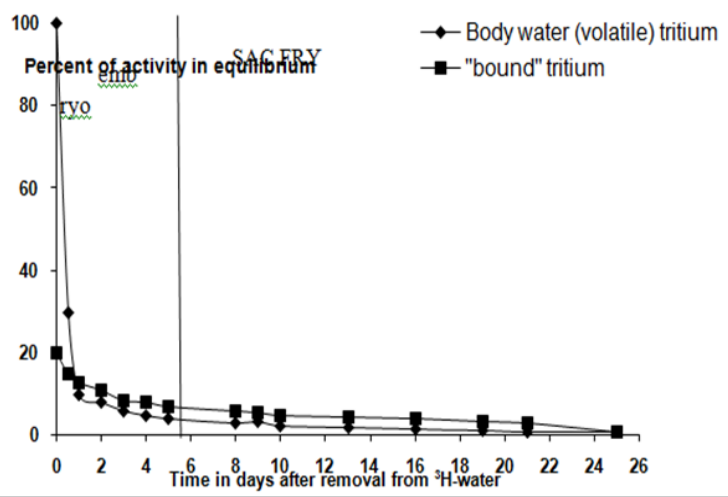

Figure 2: Retention of tritium in eggs of Carassiusgibelio

The loss of tritium upon transfer to inactive free-flowing water after exposure for 20 days at an initial level of $500 \mathrm{BqL}^{-1}$ is shown in Figure 2. For both volatile and "bound" fractions, fast and slow components of turnover are indicated. Initially, both volatile and "bound" fractions elute rapidly. A slower component of the volatile fraction persists for 17 days, as determined in development fry. The slow component of the "bound" fraction, for comparison, persists at $0.6 \%$ of the initial bound equilibrium level at 25 days. From data it was evident that exposure to tritiated water resulted in essentially a uniform distribution of the isotope in subsequently all tissues and organs of the larvae. No localization within nuclear organelles was demonstrated.

By inspection of the uptake curves in Figure 2, and with the understanding that the level of isotope in the treatment bath also decreases with time, it would appear that no concentration of tritium above the water equilibrium level had occurred. However, to adequately prove this contention, further statistical analyses normalized on a larvae weight or available water basis must be performed. Preliminary findings in support of this effort disclose an estimated concentration factor of only 0.92 to 1.1 .

The curves for elution of volatile and "bound" fractions (Figure 2), indicate, as would be expected, an exponential loss of activities over the first several days. The slopes of the curves correspond to estimated half time of $\sim 1.0$ and $2.0 \mathrm{hr}$ respectively. As expected, the rate of loss of tritium activity in the volatile fraction becomes equal to the rate of loss of the "bound" fraction. This may be attributed to the fact that after sufficient time all essentially volatile or "body water" tritium will be derived from the breakdown or turnover of "bound" tritium-containing organic compounds. The "bound" curve can be resolved fairly well into two major exponential components with slopes corresponding to biological half lives of $\sim 2.0$ hours and $\sim 8$ days. Such resolution can only be considered as an approximation of tritium-binding capacities. Undoubtedly, there are as many more components of the curves as there are compounds in the larvae that are capable of binding tritium. Further uncertainty of the half life of the longer lived components is realized because of the lack of information as to the course of the curve beyond 25 days.

\section{Radiation Effects}

Table 1: Effect of tritiated water on embryogenesis of the Carassiusgibelio

\begin{tabular}{|c|c|c|c|c|c|c|c|c|}
\hline Treatment & No. eggs & $\%$ hatch & $\begin{array}{c}95 \% \text { binomial } \\
\text { confidence limits }\end{array}$ & $\begin{array}{l}\text { No. larvae } \\
\text { sampled }\end{array}$ & $\%$ abnormal & $\begin{array}{l}\text { 95\% binomial } \\
\text { confidence } \\
\text { limits }\end{array}$ & $\begin{array}{c}28 \text { day larvae } \\
\text { length, mm + } \\
\text { S.D. }\end{array}$ & $\begin{array}{c} \pm 95 \% \\
\text { confidence } \\
\text { value }\end{array}$ \\
\hline \multicolumn{9}{|c|}{ Experiment 1} \\
\hline control & 3374 & 80.1 & 79.5-81.3 & 2258 & 1 & $0.6-1.4$ & $27.00 \pm 0.91$ & 0.06 \\
\hline $50 \mathrm{~Bq} \cdot \mathrm{L}^{-1}$ & 7789 & 78.1 & 83.1-83.9 & 6540 & 5.5 & $4.9-6.1$ & $26.89 \pm 1.04$ & 0.04 \\
\hline $500 \mathrm{~Bq} \cdot \mathrm{L}^{-1}$ & 7123 & 79.2 & 82.5-83.2 & 6392 & 3.5 & $3.0-4.0$ & $27.60 \pm 0.89$ & 0.04 \\
\hline $5000 \mathrm{~Bq} \cdot \mathrm{L}^{-1}$ & 5465 & 80.9 & 81.2-83.1 & 3938 & 3.8 & $1.4-2.3$ & $27.36 \pm 0.89$ & 0.05 \\
\hline $50000 \mathrm{~Bq} \cdot \mathrm{L}^{-1}$ & 8239 & 78.9 & $79.0-81.2$ & 4951 & 4 & $1.1-2.5$ & $27.24 \pm 0.89$ & 0.05 \\
\hline \multicolumn{9}{|c|}{ Experiment 2} \\
\hline control & 3821 & 89 & 89.8-91.3 & 2994 & 0.7 & $0.4-1.1$ & - & - \\
\hline $50 \mathrm{~Bq} \cdot \mathrm{L}^{-1}$ & 6593 & 76.1 & $67.5-69.3$ & 2828 & 1.6 & $1.2-2.1$ & - & - \\
\hline $500 \mathrm{~Bq} \cdot \mathrm{L}^{-1}$ & 3344 & 67 & $54.5-55.8$ & 2928 & 3.5 & $2.8-4.4$ & - & - \\
\hline $5000 \mathrm{~Bq} \cdot \mathrm{L}^{-1}$ & 4135 & 72 & $80.6-81.4$ & 3302 & 0.5 & $0.3-0.8$ & - & - \\
\hline $50000 \mathrm{~Bq} \cdot \mathrm{L}^{-1}$ & 5625 & 68.9 & $71.7-73.9$ & 4301 & 0.4 & $0.4-0.9$ & - & - \\
\hline
\end{tabular}




\section{Open Access Journal of Toxicology}

Table 2: Effect of tritiated water on embryogenesis of Carassiusgibelio

\begin{tabular}{|c|c|c|c|c|}
\hline \multicolumn{5}{|c|}{ Experiment 2 } \\
\hline Treatment & No. Eggs & No. Deaths through 21 days & \% Mortality through 25 days & 95 \% Binomial Confidence Limits \\
\hline control & 3166 & 270 & 8.5 & 10.7 \\
\hline $50 \mathrm{~Bq} \cdot \mathrm{L}^{-1}$ & 6946 & 747 & 12.5 & $9.9-11.6$ \\
\hline $500 \mathrm{~Bq} \cdot \mathrm{L}^{-1}$ & 3431 & 610 & 19.9 & $11.9-15.4$ \\
\hline $5000 \mathrm{~Bq} \cdot \mathrm{L}^{-1}$ & 4411 & 681 & 14 & $18.4-21.4$ \\
\hline $50000 \mathrm{~Bq} \cdot \mathrm{L}^{-1}$ & 3894 & 618 & $12.9-15.1$ & \\
\hline
\end{tabular}

The results of exposure to the four concentrations of tritiated water as determined throughout experiments are illustrated in Tables 1 \& 2. In Experiment No. 1, the 95\% Confidence Limits for each treatment compared with the control indicate that under the described experimental conditions, a statistically significant reduction in development percentage could not be demonstrated. In fact, a slight enhancement in development efficiency occurred in the $50 \mathrm{BqL}^{-1}$ and $500 \mathrm{BqL}^{-1}$ levels. No demonstrable delay in time of development for any of the three treatment levels as compared with the control was observed. A statistically significant increase in the incidence of abnormal larvae as compared with the control was encountered. The larvae in each treatment were of significantly different size than those of the control, as determined at 28 days, although the high concentration larvae of greater length.

In Experiment No. 2, the lack of rigid temperature control during the last week of development unavoidably resulted

in terminating the tritium treated lots before the, greater proportion of the larvae had hatched. The control lot developed under near normal experimental conditions. However, as in Table 2 if mortality is normalized to a period in development there environmental parameters were adequate, 21 days, then a comparison between control and each treatment level is possible.

In this case, a significant increase in the incidence of mortality as compared with the control is encountered, and which may be correlated to increasing exposure level. From Table 1 , in the systems $5000 \mathrm{BqL}^{-1}$ and $50000 \mathrm{BqL}^{-1}$ levels produced significantly more abnormal larvae than the control. For each of the procedures applied to detect "sub-lethal" effect as a result of exposure during inclusive of determinations of growth rate Table 3, relative performance to predation (Table 4) and equilibrium loss and thermal death (Table 5), no statistically significant degree of impairment was demonstrated.

Table 3: Growth of tritium-treated (50000 Bq. $\left.\mathrm{L}^{-1}\right)$ of larvae and untreated (control) of Carassiusgibelio

\begin{tabular}{|c|c|c|c|c|c|}
\hline Treatment & Larval Age (days) & No. Observations & $\begin{array}{c}\text { Mean Length } \\
\text { (mm } \pm \text { s.d) }\end{array}$ & $\begin{array}{c}\mathbf{9 5} \text { \% Confidence } \\
\text { Limits }\end{array}$ & $\begin{array}{c}\mathbf{9 5} \text { \% Confidence } \\
\text { Value }\end{array}$ \\
\hline Control & 10 & 800 & $17.36 \pm 0.89$ & $17.30-17.43$ & 0.06 \\
\hline $50000 \mathrm{~Bq} \cdot \mathrm{L}^{-1}$ & 10 & 1050 & $17.60 \pm 0.89$ & $17.55-17.66$ & 0.05 \\
\hline Control & 28 & 100 & $28.34 \pm 2.81$ & $27.78-28.90$ & 0.55 \\
\hline $50000 \mathrm{~Bq} \cdot \mathrm{L}^{-1}$ & 28 & 100 & $28.43 \pm 2.41$ & $27.95-28.91$ & 0.47 \\
\hline Control & 119 & 85 & $61.5 \pm 7.6$ & $60.5-65.2$ & 2.84 \\
\hline $50000 \mathrm{~Bq} \cdot \mathrm{L}^{-1}$ & 119 & 107 & $64.7 \pm 8.6$ & $65.1-68.3$ & 2.59 \\
\hline
\end{tabular}

Table 4: Relative performance of tritium-treated (50000 Bq· $\mathrm{L}^{-1}-21$ days during embryogenesis) and untreated (control) juvenile to predation as determined at 4 months

\begin{tabular}{|c|c|c|c|c|c|}
\hline \multicolumn{3}{|c|}{ Control } & \multicolumn{3}{|c|}{ Experimental } \\
\hline Mean length, & No. survivors & $\mathrm{X}^{2}$ & Mean length, & No. survivors & $\mathrm{t}$ \\
\hline $\mathrm{mm} \pm$ S.D. & & & $\mathrm{mm} \pm$ S.D. & & \\
\hline $60.6 \pm 3.4$ & 11 & 0.037 & $58.1 \pm 3.9$ & 12 & 3.254 \\
\hline $58.2 \pm 3.1$ & 17 & 1.025 & $61.8 \pm 5.6$ & 12 & -1.721 \\
\hline $59.5 \pm 2.8$ & 14 & 0.029 & $58.8 \pm 4.7$ & 12 & 0.864 \\
\hline $66.4 \pm 3.5$ & 12 & 0.041 & $67.9 \pm 3.4$ & 13 & -0.791 \\
\hline $59.7 \pm 5.1$ & 16 & 0.818 & $74.5 \pm 7.9$ & 6 & -1.727 \\
\hline $56.1 \pm 5.6$ & 8 & 0 & $66.8 \pm 3.4$ & 15 & 0.341 \\
\hline $57.6 \pm 4.6$ & 13 & 0 & $68.2 \pm 4.2$ & 7 & 0.306 \\
\hline $57.1 \pm 4.9$ & 9 & 0.461 & $70.4 \pm 4.3$ & 9 & -1.264 \\
\hline $68.3 \pm 6.5$ & 7 & 0.574 & $73.1 \pm 4.3$ & 5 & -2.159 \\
\hline $70.1 \pm 7.1$ & 6 & 0.35 & $74.0 \pm 6.9$ & 10 & 1.041 \\
\hline
\end{tabular}




\section{Open Access Journal of Toxicology}

\begin{tabular}{|c|c|c|c|c|c|}
\hline $69.7 \pm 6.6$ & 11 & 0 & $70.1 \pm 8.8$ & 11 & -0.872 \\
\hline $86.5 \pm 8.5$ & 10 & 0.024 & $85.3 \pm 8.9$ & 12 & 0.707 \\
\hline $81.5 \pm 7.9$ & 10 & 0.035 & $80.5 \pm 8.2$ & 8 & -1.254 \\
\hline $77.4 \pm 4.7$ & 15 & 4.225 & $76.1 \pm 6.7$ & 8 & -0.598 \\
\hline $77.8 \pm 5.8$ & 11 & 0.222 & $69.9 \pm 4.6$ & 9 & 0.891 \\
\hline $80.3 \pm 4.7$ & 13 & 0.254 & $78.9 \pm 9.3$ & 15 & 0.524 \\
\hline $65.3 \pm 2.7$ & 17 & 0.444 & $60.9 \pm 4.2$ & 11 & -0.988 \\
\hline $85.3 \pm 5.9$ & 10 & 0.333 & $78.9 \pm 7.9$ & 9 & -0.968 \\
\hline $69.6 \pm 4.3$ & 11 & 1 & $70.1 \pm 4.6$ & 14 & 0.876 \\
\hline $72.2 \pm 5.2$ & 12 & 0.267 & $71.9 \pm 4.1$ & 13 & -0.441 \\
\hline $81.2 \pm 8.6$ & 13 & 0.143 & $83.6 \pm 6.1$ & 15 & 0.75 \\
\hline
\end{tabular}

Table 5: Thermal sensitivity of tritium-treated and untreated juvenile of Carassius gibelio

\begin{tabular}{|c|c|c|c|c|c|}
\hline \multirow{2}{*}{ Temp. C } & \multirow{2}{*}{ Treatment } & \multicolumn{2}{|c|}{ Equilibrium loss time } & \multicolumn{2}{|c|}{ Death time } \\
\hline & & Geom. Mean & 95\% Confidence Limits & Geom. Mean & $\mathbf{9 5} \%$ Confidence Limits \\
\hline \multirow{2}{*}{30} & Control & 2.06 & $1.52-2.80$ & 3.21 & $2.35-4.39$ \\
\hline & $50000 \mathrm{~Bq} \cdot \mathrm{L}^{-1}$ & 1.97 & $1.43-2.71$ & 2.93 & $2.21-3.89$ \\
\hline \multirow{4}{*}{29} & Control & 12.38 & $10.87-14.10$ & 15.94 & $14.75-17.23$ \\
\hline & Control & 11.26 & $7.55-16.79$ & 15.77 & $10.75-23.14$ \\
\hline & $50000 \mathrm{~Bq} \cdot \mathrm{L}^{-1}$ & 8.77 & $5.48-14.03$ & 12.14 & $8.67-17.00$ \\
\hline & $50000 \mathrm{~Bq} \cdot \mathrm{L}^{-1}$ & 9.09 & $5.56-14.87$ & 14.53 & $11.77-17.94$ \\
\hline \multirow{8}{*}{28} & Control & 22.55 & $16.28-31.24$ & 28.75 & $22.79-36.27$ \\
\hline & Control & 11.02 & $6.50-18.68$ & 18.09 & $12.38-26.44$ \\
\hline & Control & 8.41 & $7.95-8.90$ & 10.96 & 7.01-17.14 \\
\hline & Control & 5.1 & 2.93-8.87 & 9.33 & $5.67-15.36$ \\
\hline & $50000 \mathrm{~Bq} \cdot \mathrm{L}^{-1}$ & 29.18 & $25.99-32.76$ & 36.25 & $31.61-41.58$ \\
\hline & $50000 \mathrm{~Bq} \cdot \mathrm{L}^{-1}$ & 3.43 & $2.72-4.33$ & 9.92 & $6.25-15.74$ \\
\hline & $50000 \mathrm{~Bq} \cdot \mathrm{L}^{-1}$ & 9.02 & $6.14-13.25$ & 16.12 & $11.90-21.84$ \\
\hline & $50000 \mathrm{~Bq} \mathrm{~L}^{-1}$ & 4.16 & $3.18-5.44$ & 10.39 & $6.60-16.37$ \\
\hline \multirow{2}{*}{27} & Control & 105.9 & $92.2-121.5$ & 120.3 & 110.9-130.6 \\
\hline & $50000 \mathrm{~Bq} \cdot \mathrm{L}^{-1}$ & 94.4 & $87.2-102.3$ & 114.3 & $102.5-127.5$ \\
\hline \multirow{2}{*}{26} & Control & \multirow{2}{*}{ - } & \multirow{2}{*}{ - } & 413 & $336-508$ \\
\hline & $50000 \mathrm{~Bq} \cdot \mathrm{L}^{-1}$ & & & 440 & $339-571$ \\
\hline
\end{tabular}

\section{Conclusion}

A review of all experimental results to date reveal considerable variation between similar treatments, and as great as those differences arising within treatments. Statistically significant reduction in the proportions of larvae attaining a particular stage in development could not be demonstrated consistently.

Although a statistically significant increase in incidence of abnormal larvae as compared with controls is encountered in most all treatments, the degree of increase could not be correlated to increasing exposure level. Impairment at the higher exposure levels cannot be detected with the criteria presently applied; that is larvae abnormality and such "sub-lethal" indices as growth, predation, equilibrium loss and thermal death.

\section{Acknowledgment}

The study was financially supported in part by the Russian Foundation for Basic Research, project no. 05-16-00205.

\section{References}

1. IAEA (1979) Environmental Isotope Data World survey of isotope concentration in precipitation 426 IAEA, Vienna. 5 (1972-1975).

2. US (1999) Nuclear Weapon Accident Response Procedures (NARP) DoD 3150.8-M

3. Radiation Safety Standards (1999) Ministry for Health of the Russian Federation p. 115, Moscow, Russian.

4. Konig LA (1990) Tritium in the food chain. Radiation Protection Dosimetry 30(2): 77-86.

5. Galeriu D, Heling R, Melintescu A (2005) The dynamics of tritiumincluding OBT in the aquatic food chain. Fusion Sci Technol 48: 779782. 
6. Weiss W, Bullacher J, Roether W (1979) Evidence of pulsed discharges of tritium from nuclear energy installations in central European precipitation. In: Behaviour of Tritium in the Environment. Vienna, pp. 17-30

7. Melintescu A, Galeriu D (2011) Dynamic model for tritium transfer in an aquatic food chain. Radiat Environ Biophys 50(3): 459-473.

8. Melintescu A, Galeriu D, Kim SB (2011) Tritium dynamics in large fish-a model test. Radioprotection 46(6): S431-S436.

9. Murphy CE (1984) The relationship between tritiated water activities in air, vegetation, and soil under steady-state conditions. Health Phys 47: 635-639.

10. Murphy CE (1993) Tritium Transport and Cycling in the Environment Health Phys. 65(6): 683-697.

11. Galeriu D (2010) Tritium Radio nuclides in the Environment. Ed. David A. Atwood, John Wiley\& Sons Ltd, West Sussex, England, pp. 47-65.

12. Kim SB, Shultz C, Stuart M, McNamara E, Festarini A, et al. (2013) Organically bound tritium (OBT) formation in rainbow trout (Oncorhynchus mykiss): HTO and OBT-spiked food exposure experiments. Appl Radiat Isot.72: 114-122.

13. Bondareva L (2011) Natural Occurrence of Tritium in the Ecosystem of the Yenisei River. Fusion Science and Technology 60(4): 1304-1307.

14. NCRP National Council on Radiation Protection and Measurements
(1976) Tritium Measurement Techniques. NCRP, Washington, USA, pp. $12-66$

15. Bondareva LG, Pomozova NV (2009) Study of the influence of different types of extinguishing on the tritium measurement efficiency in the environment. Journal of SFU 2(1): 56-60.

16. Afanasov MI (2012) Principles of Radiochemistry and Radioecology. Practical Works. Moscow, Russian, p. 214.

17. ISO Water quality. Determination of tritium activity concentrationLiquid scintillation counting method. 9698:2010 p. 24.

18. Nikolov J, Todorovica N, Jankovic M, Vostinar M, Istvan B, et al. (2013) Different methods for tritium determination in surface water by LSC. Applied Radiation and Isotopes 71(1): 51-56.

19. Fukutan S, Fukui M, Akio KA, Nishimaki K (2008) A Method of Calibration for Measurement of Low Level Tritium in Environmental Water using a Liquid Scintillation Counter. Journal of Nuclear Science and Technology 6: 89-92.

20. Bams RA (1967) Differences in Performance of Naturally and Artificially Propagated Sockeye Salmon Migrant Fry, as Measured with Swimming and Predation Tests. Journal of the Fisheries Research Board of Canada 24(5): 1117-1153.

21. Bayley M, Junge M, Baatrupm E (2002) Exposure of juvenile guppies to three antiandrogens causes demasculinization and a reduced sperm count in adult males. Aquat Toxicol 56: 227-239.

\begin{tabular}{l} 
Your next submission with Juniper Publishers \\
will reach you the below assets \\
- Quality Editorial service \\
- Swift Peer Review \\
- Reprints availability \\
- E-prints Service \\
- Manuscript Podcast for convenient understanding \\
- Global attainment for your research \\
- Manuscript accessibility in different formats \\
( Pdf, E-pub, Full Text, Audio) \\
- Unceasing customer service \\
Track the below URL for one-step submission \\
https://juniperpublishers.com/online-submission.php \\
\hline
\end{tabular}

